\title{
Development and quality evaluation of mango and guava blended squash during storage
}

\author{
Muhammad Noor uddin ${ }^{1 *}$, Said Wahab ${ }^{1}$, Ali Muhammad ${ }^{1}$, Haris \\ Bilal $^{1}$, Mukhtar Ud Din ${ }^{2}$, Haq Nawaz ${ }^{3}$, Shahid Ali Khan ${ }^{1}$ and Qaiser \\ Ali Sultan ${ }^{1}$ \\ 1. Department of Food Science and Technology, the University of Agriculture Peshawar-Pakistan \\ 2. Department of Human Nutrition, the University of Agriculture Peshawar-Pakistan \\ 3. Department of Agronomy, the University of Agriculture Peshawar-Pakistan \\ *Corresponding author's email: norrudin555@gmail.com \\ Citation
}

Muhammad Noor uddin, Said Wahab, Ali Muhammad, Haris Bilal, Mukhtar Ud Din, Haq Nawaz, Shahid Ali Khan and Qaiser Ali Sultan. Development and quality evaluation of mango and guava blended squash during storage. Pure and Applied Biology. Vol. 8, Issue 2, pp1182-1190. http://dx.doi.org/10.19045/bspab.2019.80060 \begin{tabular}{llll}
\hline \hline Received: 03/01/2019 & Revised: 04/04/2019 & Accepted: 10/04/2019 & Online First: 13/04/2019 \\
\hline
\end{tabular}

\section{Abstract}

The study was taken out on the diverse ratio and storage period to evaluate the superiority of mango and guava blended squash. The future perspective of this study was to prepare a new product with good storage time and keeping quality with good colour and flavor. Squash was prepared from two diverse fruits by integration pulp, sugar and water in the ratio of 1:4:1 respectively. Potassium meta-bisulphite was added at $0.01 \%$ to all formulation. Every one sample were filled in two hundred and fifty $\mathrm{ml}$ plastic bottles and kept at room temperature for ninety days. The samples were evaluated for $\mathrm{pH}$, total soluble solids, percent acidity, vitamin $\mathrm{C}$, reducing and non-reducing sugars and sensory analysis for color, flavor and overall acceptability for three months in total with an interval of fifteen days for each reading. During storage, $\mathrm{pH}$ increased from 2.75 to 3.1 , percent acidity increased from 1.45 to 1.27 , total soluble solids increased from 46.67 to 48.30 , ascorbic acid decreased from 36.30 to 34.34, reducing sugar increased from 14.17 to 15.73 , non-reducing sugar dwindled from 28.30 to 26.67 , color declined from 8.20 to 6.00 , flavor value reduced from 8.50 to 6.10 and overall acceptability dwindled 8.00 to 6.10 throughout time of storage. The results displays that storage time and treatments had considerable influence $(\mathrm{p}<0.05)$ on physic-chemical and sensory assessment of Mango and guava blended squash. The squash sample $\mathrm{M}_{3}$ was found excellent followed by $\mathrm{M}_{7}$, while $\mathrm{M}_{1}$ display bad results.

Keywords: Mango Guava blended squash; Potassium Meta-bisulphite; Sensory evaluation;

Storage

\section{Introduction}

Myrtaceae is the family of guava having more than eighty genera and three hundred species; which are grown throughout the tropics and subtropics i.e in America, Asia and Australia [1]. The guava shows toleration in climates such as frost free [2]. Guava is the precursor of ascorbic acid, calcium, vitamin A and dietary fiber. Pectin is found in its flesh and used for jam and jellies making [3].

In Pakistan guava occupies $3^{\text {rd }}$ major position on cultivated basis fruit after citrus and mango. Combined area of Apples and peaches (4900hac) is less than its area. Dispersing in huge area of country shows 
the reality of guava is drought tolerant, hardiest and keeps the $\mathrm{pH}$ among 4.5 to 8.5 [4]. Within Pakistan after bananas, mango and citrus its production takes $4^{\text {th }}$ rank. However, its yield is 8.1 tones/hac, which is less than yield of 25 tonnes/ha [5]. Punjab districts climate and soil are suitable for guava crops, more occurs in these areas. In Larkana, Dadu Shikarpur and Hyderabad district of Sindh, smaller seed pear shaped guava grown. Famous areas in Khyber Pakhtunkhwa for guava production having good quality are Haripur, Dera Ismail Khan, Malakand, Bannu and Kohat 18,570 tons of guava are produced during 2004 to 2005 in Khyber Pakhtunkhwa under cultivation area of 1551 hectares. Of these $33 \%$ produced in Kohat [6].

Mango (Mangiferaindica L.) which belongs to the family Anacadiacease, is one of the main cultured fruit in the world [7]. Pakistan mango fabrication in 2009-10 was 1847,000 tones [8]. Mango is processed in several types of juices, chutneys, pickle, jams, nectars, squashes, mango toffees, canned mango slices and frozen mango slices and so on. It serves as a first-class basis of energy and provides vitamins $\mathrm{C}, \mathrm{A}$ and minerals like $\mathrm{Fe}$ and phosphorus [9]. The fruit tissue of a matured mango contains up to $15 \%$ sugar and up to $1 \%$ protein. Additionally, mango has antioxidant, anticancer and anti-cvs abilities. Furthermore due to the high iron contents this fruit is a potential supplement for the handling of anemia, good diet for women during pregnancy and menstruation. Mangoes also contain amylase enzyme with stomach gentle properties analogous to pepsin that helps in digestion.

Squashes are syrupy juices containing some pulp. The term "jovial" is regularly worn interchangeably with squash. Fruit squashes have a lowly quantity of twenty five percent via capacity of fruit juice and are proposed to be drunk after dilution. Whereas Sulphur dioxide $\left(\mathrm{SO}_{2}\right)$ is the classic chemical addition for squashes, benzoic acid is used commonly. The acidities are generally in the mixture of 1.5 to 2.5 per w/v citric acid. The squash is packed into washed and pure bottles, exit with plan to one inch top space. The bottles are blocked with peak. The squash placed in safe for one to 1.5 years with no a large amount change in color or tastes [10].

\section{Materials and methods}

Reverberation, vigorous Mango and Guava of exact bulk and finest ripeness was purchased from the confined market of Peshawar and brought to the laboratories of Food Science and Technology, The University of Agriculture, Peshawar, Pakistan where this research work was conducted.

\section{Preparation of samples}

Subsequent to washing and arrangement, the stalks of Mango and Guava fruits were removed with the help of stainless steel knives.

\section{Pulp extraction}

Mango and Guava pulp was extracted by a pulper. Mango and Guava were put into the machine and pulp was obtained. The pulp was strained through muslin cloth and was used for squash preparation.

\section{Preparation of squash}

Mango and Guava squash was set by integration pulp, sugar and water in ratio of 1:4:1. Citric acid was supplementary to regulate the acidity to one percent along with $0.05 \%$ Carboxyl Methyl Cellulose (CMC) to avoid separation [11].

\section{Packaging and storage of squash}

The ready squash samples were packed in $250 \mathrm{ml}$ capability obvious plastic bottles and were reserved at room temperature for Physicochemical and Sensory analysis at intervals of fifteen days for entire time of three months.

\section{Physico-chemical analysis}

Digital $\mathrm{pH}$ meter was used to determine the $\mathrm{pH}$ according to standard method of [12]. Total soluble solids (TSS) were determined by using hand refractometer at room temperature [12]. Acidity was determined by standard method [12]. Ascorbic acid was determined by the direct colorimetric method using 2,6-dichlorophenol- 
indophenols as decolorizing agent by ascorbic acid in sample extract and in standard ascorbic acid solution [12]. Reducing and non-reducing sugars were determined by Lane Eynon method [12].

\section{Organoleptic evaluation}

The samples of Mango and Guava blended squash were studied organoleptically for color, flavor, and overall acceptability by ten judge's panel. Organoleptic study was carried out at the storage intervals of fifteen days with an overall period of three months. The evaluation was conceded out by using 9 points hedonic scale of [13].

\section{Statistical analysis}

Every one data concerning treatments and storage period were statistically analyzed by means of Complete Randomized Design (CRD) as suggested by [14] and the means were divided by applying LSD Test at five percent probability level as described by Steel and Torrie [15].

\section{Results and discussion}

\section{Physico-chemical analysis}

Mango and Guava blended squash was ready by mixing pulp, sugar and $\mathrm{H}_{2} \mathrm{O}$ in the proportion of $1: 4: 1$ respectively. Then the squash samples were evaluated physicochemical for vitamin $\mathrm{C}, \mathrm{pH}$, percent acidity, Total soluble solids, reducing and non-reducing sugars and organoleptic characteristics that is color, flavor and overall acceptability. These parameters are discussed as under:

The statistical analyses showed that the treatments and storage time had a significant $(\mathrm{p}<0.05)$ influence on $\mathrm{pH}$ of Mango and Guava blended squash through storage at room temperature. (Table 1). $\mathrm{pH}$ is responsible for flavors and preservation of Mango and guava blended squash. In the beginning, of an experiment, the $\mathrm{pH}$ values of the samples were noted as 2.82, 2.71, $2.70,2.79,2.76,2.77$ and 2.72 which gradually increase to $3.31,3.13,2.99,3.12$, 3.113 .10 and 3.04 correspondingly during 90 days of storage time at room temperature. The mean $\mathrm{pH}$ values greatly $(\mathrm{p}<0.05)$ enlarge from 2.75 to 3.11 . For treatments, maximum value for was noted in $\mathrm{M}_{1}$ (3.07), followed by $\mathrm{M}_{3}$ (2.96), while minimum value for mean was noted in $\mathrm{M}_{3}$ (2.84), followed by $\mathrm{M}_{7}$ (2.86). Maximum percent increase was noted in $\mathrm{M}_{1}(14.80 \%)$, followed by $\mathrm{M}_{1}(13.42 \%)$. While minimum percent reduce was noted in $\mathrm{M}_{3}(9.70 \%)$, followed by $\mathrm{M}_{7}$ (Table 1). Equivalent observation was observed by [16] in Kinnow mandarin ginger squash. $\mathrm{pH}$ of fruits and vegetables changes it might be due to heat treatment on biochemical substances, decrease of respiration and metabolic process. In the same way increase in $\mathrm{pH}$ during storage period of the squash was observed by [17].

The statistical analysis showed that the treatments and storage had a substantial $(\mathrm{p}<0.05)$ influence on titratable acidity of Mango and guava squash through storage at room temperature. (Table 2). Initially the titratable acidity of the samples were 1.43 , $1.45,1.46,1.45,1.47,1.48,1.47$ percent which were gradually decreased to 1.20 , $1.28,1.30,1.26,1.29,1.29$ and 1.30 percent correspondingly during three months of storage at room temperature. The mean values of acidity substantially $(\mathrm{p}<0.05)$ decline from 1.45 to 1.30 . For treatments, maximum mean value was observed in $\mathrm{M}_{3}$ (1.39), followed by $\mathrm{M}_{6}$ (1.38) while minimum value for mean was noted in $\mathrm{M}_{1}$ (1.32), followed by $\mathrm{M}_{4}$ (1.37). Maximum percent decreased was noted in $\mathrm{M}_{1}$ (16.08\%), followed by $\mathrm{M}_{4}(13.10 \%)$ and lowest percent decrease was noted in $\mathrm{M}_{3}$ (10.96\%), followed by $\mathrm{M}_{7}(11.56 \%$ ) (Table 2 ). This dwindle may be because of acid hydrolysis of polysaccharides and nonreducing sugars to their monomers where the acid is used for change them to six carbon sugars or polymers in the existence of metal ions. Similar result was reported by [18] in amla juice. Decline in acidity during the storage period of the beverages was observed by [19] in flavored tamarind Ready to serve beverages and [20] in Ready to serve beal guava beverage.

The statistically analysis showed that the treatments and storage intervals had a substantial $(\mathrm{p}<0.05)$ influence on Total 
soluble solids of Mango and Guava squash through storage at room temperature. (Table 3). At the begin of an experiment, the TSS values of the samples were recorded as, 47.50, 47.60, 47.30, 47.20, $45.60,45.70$ and 45.80 , ${ }^{0}$ brix which were gradually increased to $50.10,49.10,48.50$, $48.90,47.10,47.40$ and $47.00^{\circ}$ brix correspondingly during three months of storage. The mean Total soluble solids values considerably $(\mathrm{p}<0.05)$ enlarge from 46.67 to $48.30^{\circ}$ brix during storage. For treatments maximum mean values was eminent in $M_{1}$ (48.60), followed by $M_{2}$ (48.30) while minimum mean value was noted in $\mathrm{M}_{5}$ (46.30), followed by $\mathrm{M}_{7}$ (46.30). Maximum percent enlarge was noted in $\mathrm{M}_{1}(5.19 \%)$, followed by $\mathrm{M}_{6}$ (3.59\%) while minimum percent increase was noted in $\mathrm{M}_{3}(2.47 \%)$, followed by $\mathrm{M}_{7}$ $(2.55 \%)$ (Table 3$)$. This is enlarge during storage period due to conversion of sucrose into (glucose fructose). These results are in conformity with [17]. Comparable explanations were recorded by [21] in tamarind syrup and [16] in ginger mixed kinnow mandarin squash.

The statistical analysis showed that the treatments and storage intervals had a substantial $(p<0.05)$ influence on vitamin $C$ content of Mango and guava squash throughout storage at room temperature (Table-4). At the begin of an experiment, the ascorbic acid content of the samples were $33.05,34.40,34.51,34.5,39.30$, 39.25 and $39.10 \mathrm{mg} / 100 \mathrm{~g}$, which were step by step decreased to $28.40,32.50,33.50$, $33.00,37.75,37.33$ and $37.90, \mathrm{mg} / 100 \mathrm{~g}$ correspondingly throughout three months of storage time at room temperature. The mean values of vitamin $\mathrm{C}$ content considerably $(\mathrm{p}<0.05)$ declined as of 36.30 to $34.34 \mathrm{mg} / 100 \mathrm{~g}$. For treatments, maximum mean value was noted in $\mathrm{M}_{6}$ (38.93), followed by $\mathrm{M}_{7}$ (38.58). While minimum mean value was noted in $\mathbf{M}_{1}$ (31.26), followed by $\mathrm{M}_{2}$ (33.37). Maximum percent reduce was noted in $\mathrm{M}_{1}(14.07 \%)$, followed by $\mathrm{M}_{2}(5.52 \%)$, while minimum percent reduce was noted in $\mathrm{M}_{3}(2.93 \%)$, followed by $\mathrm{M}_{7}(3.06 \%)$ (Table 4). The loss in ascorbic acid due to environmental factors like high temperature, heat and light. Slowly dwindle of vitamin C content may be due to oxidative destruction of ascorbic acid in the presence of molecular oxygen by enzymes [22]. Comparable details for diminish in vitamin $\mathrm{C}$ content was observed in aonla juice by Gajanana [18], in rose apple aonla squash by [23].

The statistical analysis showed that the treatments and storage time had a substantial $(\mathrm{P}<0.05)$ influence on reducing sugars of Mango and guava squash throughout storage at ambient temperature. (Table-5). At the begin of an experiment the reducing sugar of the samples were $15.27,14.91,14.39,14.39,13.42,13.40$ and 13.43 , which were gradually increased to $18.30,16.35,15.90,13.50,14.90,14.50$ and 14.00 respectively during 90 days of storage period at room temperature. Mean values of reducing sugar significantly $(\mathrm{P}<0.05)$ enlarged from 14.17 to 15.73 from beginning to end storage. For treatments, maximum value for mean was noted in $\mathrm{M}_{1}$ (16.64), followed by $\mathrm{M}_{2}$ (15.43), while minimum value for mean was noted in $\mathrm{M}_{7}$ (13.66), followed $\mathrm{M}_{6}$ (14.00). Maximum percent increase was noted in $\mathrm{M}_{1}(16.56 \%)$; followed by $\mathrm{M}_{3}(11.17 \%)$ while minimum percent increase was noted in $\mathrm{M}_{3}(8.81 \%)$, followed by $\mathrm{M}_{4}(9.50 \%)$ (Table 5). It might been dorsed to the acid splitting by water of polysaccharides which resulted in expansion in soluble sugars content. Increase can be accredited to the hydrolysis of non-reducing sugars due to processing and storage. Comparable findings were observed by [21] in tamarind syrup and [24] in mango lemon grass beverage in total and reducing sugars and decline in nonreducing-sugars throughout storage.

The statistical analysis showed that the treatments and storage intervals had a substantial $(\mathrm{p}<0.05)$ influence on nonreducing sugars of Mango and Guava squash throughout storage at room temperature. (Table 6). At the begin of an experiment, the non-reducing sugars of the 
samples were 29.22, 28.12, 28.30, 28.30, $27.20,28.40$ and 28.60 which were slowly decreased to $26.0,26.50,27.37,26.84$ respectively during 90 days of storage time at room temperature. The mean values of non-reducing sugars drastically $(\mathrm{p}<0.05)$ decline as of 28.30 to 26.67 throughout storage. For treatments, maximum value for mean was noted in $\mathrm{M}_{7}$ (28.26), followed by $\mathrm{M}_{1}$ (27.83) while minimum mean value was noted in followed by $\mathrm{M}_{5}$ (26.41), followed by $\mathrm{M}_{2}$ (27.41). Highest percent diminish was noted in $\mathrm{M}_{1}(11.02 \%)$, followed by $\mathrm{M}_{5}$ (6.25\%), whereas lowest percent diminish was noted in $\mathrm{M}_{3}(3.29 \%)$, followed by $\mathrm{M}_{7}$ $(3.84 \%)$ (Table 6). The dwindled due to the inversion of non-reducing sugars to reducing sugars. These consequences are in close conformity with the conclusion of [25], who showed that the contents of sucrose in the fruit was tainted to glucose and sucrose throughout storage.

The samples of Mango and Guava squash of this research work stored at room temperature were examine subjectively for colour, flavour and overall acceptability at fifteen days intervals, for an entire time of three months. The organoleptic analysis was conceded by means of 9 points hedonic scale of [13].

The statistical analysis showed that the treatments and storage intervals had a substantial $(p<0.05)$ influence on the colour of mango and guava blended squash during storage at room temperature. (Table 7). Firstly the mean score of judges for colour of samples were $8.90,8.70,8.60,8.40$, $7.40, \quad 7.70$ and 8.00 which were progressively decreased to $3.70,6.80,7.00$, $6.60,5.70,6.20$ and 6.50 correspondingly during storage. The overall mean score of judges for colour drastically $(\mathrm{p}<0.05)$ decline from 8.24 to 6.007 . For treatments, maximum value for mean was noted in $\mathrm{M}_{3}$ (7.90), followed by $M_{2}$ (7.70), while minimum value for mean was noted in $\mathrm{M}_{1}$ (6.20), followed by $M_{5}$ (6.60). Maximum percent dwindle was noted in $\mathrm{M}_{1}(58.43 \%)$, followed by $\mathrm{M}_{5}(22.97 \%$ ), while minimum mean score was noted in $\mathrm{M}_{3}(18.60 \%)$, followed by $\mathrm{M}_{7}$ (18.75\%) (Table 7). Decrease in color and flavor due to bacterial fermentation in fruit beverages could cause off color and flavor. These conclusions of the research work are also in close conformity with the findings of [26], who observed a reduction in color of fruit flavored beverages. Similarly these findings are also in concurrence with the results of [27], who showed losses in color of kinnow and strawberry blended juice during storage of three months.

The statistical analysis showed that the treatments and storage intervals had a substantial $(\mathrm{p}<0.05)$ influence on flavour of Mango and guava blended squash throughout storage at room temperature (Table 8). Initially the mean score of judges for flavour of samples were 9.00, 8.80, $8.70,8.30,8.20,8.30$ and 8.40 which were gradually decreased to $3.50,6.40,7.20$, $6.00,6.30,6.60$ and 6.90 correspondingly through storage. The overall mean score of judges for flavor drastically $(\mathrm{p}<0.05)$ decline from 8.52 to 6.12 . For Treatments, maximum value for mean was noted in sample $M_{3}$ (8.00), followed by $M_{7}$ (7.70), while minimum value for mean was noted in sample $M_{1}$ (6.10), followed $M_{4}$ (7.20). Maximum percent dwindled was noted in $\mathrm{M}_{1}(61.11 \%)$, followed $\mathrm{M}_{4}(27.71 \%)$, while minimum mean score was noted inM $_{3}$ (17.24\%), followed $\mathrm{M}_{7}(17.85 \%)$ (Table 8). These conclusion are in close agreement with the results by [28], who reported reduction in organoleptic attributes of pasteurized orange juices, kept in transparent glass bottles. Similarly, these findings are also in agreement with the results of [29], who noted a loss in flavour of guava squash during storage of 90 days. The statistical analysis showed that the results of treatments and storage intervals had a substantial $(\mathrm{p}<0.05)$ influence on overall acceptability of mango and guava blended squash throughout storage at room temperature which is presented in (Table 9). At the start the mean score of judges for overall acceptability of samples were 8.00, $8.00,8.00,8.00,8.00,8.00$ and 8.00 which 
were gradually decline to $3.80,6.30,6.80$, 6.40 and also 3.70, 6.20, 6.60 and 6.80 correspondingly through storage. The overall mean score of judges for overall acceptability substantially $(\mathrm{p}<0.05)$ decline from 8.00 to 6.15. For treatments, maximum value for mean was noted in $\mathrm{M}_{7}$ (7.50), followed $\mathrm{M}_{3}$ (7.40), while minimum value for mean was noted in $\mathrm{M}_{1}$ (5.90), followed $\mathrm{M}_{5}$ (7.10). Maximum percent reduce was noted in $\mathrm{M}_{1}(52.50 \%)$, followed $\mathrm{M}_{5}(22.50 \%)$, while minimum mean score was noted in $M_{3}$ (15.00), followed by $M_{7}$
(15.00) (Table 10). Decrease due to increasing storage time and temperature cause progressive degradation which lead to dwindled in overall acceptability. These consequences are in close conformity with the results of [30], who noted that rising storage time and temperature results in slow degradations which ultimately results in reduce in overall acceptability. Similarly, these findings are also in accordance with the results of [29], who reported a reduction in overall acceptability of guava squash during storage of 90 days.

Table 1. pH of mango and Guava blended squash during storage

\begin{tabular}{|c|c|c|c|c|c|c|c|c|c|}
\hline \multirow{2}{*}{ Treatments } & \multicolumn{7}{|c|}{ Storage Intervals } & \multirow{2}{*}{ Inc } & \multirow{2}{*}{ Means } \\
\cline { 2 - 11 } & Initial Day & $\mathbf{1 5}$ & $\mathbf{3 0}$ & $\mathbf{4 5}$ & $\mathbf{6 0}$ & $\mathbf{7 5}$ & $\mathbf{9 0}$ & & \\
\hline $\mathbf{M}_{\mathbf{1}}$ & 2.82 & 2.9 & 2.98 & 3.08 & 3.17 & 3.24 & 3.31 & 14.80 & $3.07 \mathrm{a}$ \\
\hline $\mathbf{M}_{\mathbf{2}}$ & 2.71 & 2.78 & 2.85 & 2.89 & 2.97 & 3.05 & 3.13 & 13.42 & $2.91 \mathrm{c}$ \\
\hline $\mathbf{M}_{\mathbf{3}}$ & 2.7 & 2.75 & 2.79 & 2.84 & 2.89 & 2.93 & 2.99 & 9.70 & $2.84 \mathrm{~d}$ \\
\hline $\mathbf{M}_{\mathbf{4}}$ & 2.79 & 2.86 & 2.91 & 2.96 & 3.02 & 3.07 & 3.12 & 10.58 & $2.96 \mathrm{~b}$ \\
\hline $\mathbf{M}_{\mathbf{5}}$ & 2.76 & 2.81 & 2.86 & 2.92 & 2.97 & 3.05 & 3.11 & 11.25 & $2.93 \mathrm{~b}$ \\
\hline $\mathbf{M}_{\mathbf{6}}$ & 2.77 & 2.81 & 2.88 & 2.91 & 2.98 & 3.06 & 3.1 & 10.65 & $2.93 \mathrm{~b}$ \\
\hline $\mathbf{M}_{\mathbf{7}}$ & 2.72 & 2.75 & 2.79 & 2.86 & 2.92 & 2.97 & 3.04 & 10.53 & $2.86 \mathrm{~b}$ \\
\hline $\mathbf{M e a n s}$ & $2.76 \mathrm{a}$ & $2.81 \mathrm{~b}$ & $2.87 \mathrm{c}$ & $2.93 \mathrm{~d}$ & $2.99 \mathrm{e}$ & $3.06 \mathrm{f}$ & $3.12 \mathrm{~g}$ & & \\
\hline
\end{tabular}

Figures with diverse small letters are statistically diverse $(\mathrm{P}<0.05)$

Table 2. Acidity of mango and guava blended squash during storage

\begin{tabular}{|c|c|c|c|c|c|c|c|c|c|}
\hline \multirow{2}{*}{ Treatments } & \multicolumn{7}{|c|}{ Storage Intervals } & \multirow{2}{*}{ Means } \\
\cline { 2 - 11 } & Initial Day & $\mathbf{1 5}$ & $\mathbf{3 0}$ & $\mathbf{4 5}$ & $\mathbf{6 0}$ & $\mathbf{7 5}$ & $\mathbf{9 0}$ & $\mathbf{D e c}$ & \\
\hline $\mathbf{M}_{\mathbf{1}}$ & 1.43 & 1.4 & 1.38 & 1.32 & 1.3 & 1.26 & 1.2 & 16.08 & $1.32 \mathrm{~d}$ \\
\hline $\mathbf{M}_{\mathbf{2}}$ & 1.45 & 1.43 & 1.42 & 1.39 & 1.35 & 1.31 & 1.28 & 11.72 & $1.37 \mathrm{c}$ \\
\hline $\mathbf{M}_{\mathbf{3}}$ & 1.46 & 1.44 & 1.43 & 1.4 & 1.37 & 1.34 & 1.3 & 10.96 & $1.39 \mathrm{ab}$ \\
\hline $\mathbf{M}_{\mathbf{4}}$ & 1.45 & 1.43 & 1.42 & 1.38 & 1.36 & 1.3 & 1.26 & 13.10 & $1.37 \mathrm{c}$ \\
\hline $\mathbf{M}_{\mathbf{5}}$ & 1.47 & 1.45 & 1.4 & 1.35 & 1.33 & 1.31 & 1.29 & 12.24 & $1.37 \mathrm{c}$ \\
\hline $\mathbf{M}_{\mathbf{6}}$ & 1.48 & 1.45 & 1.43 & 1.38 & 1.34 & 1.32 & 1.29 & 12.84 & $1.38 \mathrm{bc}$ \\
\hline $\mathbf{M}_{\mathbf{7}}$ & 1.47 & 1.46 & 1.44 & 1.41 & 1.39 & 1.36 & 1.30 & 11.56 & $1.40 \mathrm{a}$ \\
\hline $\mathbf{M e a n n s}$ & $1.45 \mathrm{a}$ & $1.43 \mathrm{ab}$ & $1.41 \mathrm{c}$ & $1.37 \mathrm{~d}$ & $1.34 \mathrm{e}$ & $1.31 \mathrm{f}$ & $1.27 \mathrm{~g}$ & & \\
\hline
\end{tabular}

Figures with diverse small letters are statistically diverse $(\mathrm{P}<0.05)$

Table 3. Total soluble solids of mango and guava blended squash during storage

\begin{tabular}{|c|c|c|c|c|c|c|c|c|c|}
\hline \multirow{2}{*}{ Treatments } & \multicolumn{7}{|c|}{ Storage Intervals } & \multirow{2}{*}{ \% Inc } & \multirow{2}{*}{ Means } \\
\cline { 2 - 11 } & Initial Day & $\mathbf{1 5}$ & $\mathbf{3 0}$ & $\mathbf{4 5}$ & $\mathbf{6 0}$ & $\mathbf{7 5}$ & $\mathbf{9 0}$ & & \\
\hline $\mathbf{M}_{\mathbf{1}}$ & 47.5 & 47.8 & 48 & 48.5 & 48.9 & 49.3 & 50.1 & 5.19 & $48.5 \mathrm{a}$ \\
\hline $\mathbf{M}_{\mathbf{2}}$ & 47.6 & 47.8 & 48 & 48.2 & 48.5 & 48.9 & 49.1 & 3.05 & $48.3 \mathrm{~b}$ \\
\hline $\mathbf{M}_{\mathbf{3}}$ & 47.3 & 47.5 & 47.7 & 47.9 & 48.1 & 48.3 & 48.5 & 2.47 & $47.9 \mathrm{c}$ \\
\hline $\mathbf{M}_{\mathbf{4}}$ & 47.2 & 47.5 & 47.8 & 48 & 48.3 & 48.6 & 48.9 & 3.48 & $48.0 \mathrm{c}$ \\
\hline $\mathbf{M}_{\mathbf{5}}$ & 45.6 & 45.8 & 46.1 & 46.2 & 46.5 & 46.8 & 47.1 & 3.18 & $46.3 \mathrm{~d}$ \\
\hline $\mathbf{M}_{\mathbf{6}}$ & 45.7 & 45.9 & 46.2 & 46.3 & 46.8 & 47.1 & 47.4 & 3.59 & $46.4 \mathrm{~d}$ \\
\hline $\mathbf{M}_{\mathbf{7}}$ & 45.8 & 45.9 & 46 & 46.1 & 46.4 & 46.9 & 47.0 & 2.55 & $46.3 \mathrm{~d}$ \\
\hline Means & $46.67 \mathrm{~g}$ & $46.88 \mathrm{f}$ & $47.11 \mathrm{e}$ & $47.31 \mathrm{~d}$ & $47.64 \mathrm{c}$ & $47.98 \mathrm{~b}$ & $48.3 \mathrm{a}$ & & \\
\hline
\end{tabular}

Figures with diverse small letters are statistically diverse $(\mathrm{P}<0.05)$ 
Table 4. Ascorbic Acid of mango and guava blended squash during storage

\begin{tabular}{|c|c|c|c|c|c|c|c|c|c|}
\hline \multirow[b]{2}{*}{ Treatments } & \multicolumn{7}{|c|}{ Storage Intervals } & \multirow{2}{*}{$\begin{array}{c}\% \\
\text { Dec }\end{array}$} & \multirow[b]{2}{*}{ Means } \\
\hline & $\begin{array}{c}\text { Initial } \\
\text { Day }\end{array}$ & 15 & 30 & 45 & 60 & 75 & 90 & & \\
\hline $\mathbf{M}_{1}$ & 33.05 & 32.8 & 32.4 & 32 & 31 & 29.2 & 28.4 & 14.07 & $31.26 \mathrm{~d}$ \\
\hline $\mathbf{M}_{2}$ & 34.4 & 34.1 & 33.7 & 33 & 33.1 & 32.8 & 32.5 & 5.52 & $33.37 \mathrm{c}$ \\
\hline $\mathbf{M}_{3}$ & 34.51 & 34.4 & 34.3 & 34.1 & 34.00 & 33. & 33.5 & 2.93 & $34.09 \mathrm{~b}$ \\
\hline $\mathbf{M}_{4}$ & 34.57 & 34.3 & 34.2 & 34.00 & 33.7 & 33.3 & 33 & 4.54 & $33.87 \mathrm{bc}$ \\
\hline $\mathbf{M}_{5}$ & 39.3 & 39.15 & 38.9 & 39.5 & 39.12 & 38.83 & 38.52 & 3.94 & $38.93 \mathrm{a}$ \\
\hline $\mathbf{M}_{6}$ & 39.2 & 39.05 & 38.72 & 38.41 & 38.22 & 37.75 & 37.33 & 4.77 & $38.38 \mathrm{a}$ \\
\hline $\mathbf{M}_{7}$ & 39.1 & 39 & 38.8 & 38.61 & 38.43 & 38.27 & 37.90 & 3.06 & $38.58 \mathrm{a}$ \\
\hline Means & $36.30 \mathrm{a}$ & $36.11 \mathrm{ab}$ & $35.86 \mathrm{abc}$ & $35.66 \mathrm{bc}$ & $35.36 \mathrm{~cd}$ & $34.85 \mathrm{de}$ & $34.34 \mathrm{e}$ & & \\
\hline
\end{tabular}

Figures with diverse small letters are statistically diverse $(\mathrm{P}<0.05)$

Table 5. Reducing sugar of mango and guava blended squash during storage

\begin{tabular}{|c|c|c|c|c|c|c|c|c|c|}
\hline \multirow{2}{*}{$\begin{array}{c}\text { Treatment } \\
\mathbf{s}\end{array}$} & \multicolumn{7}{|c|}{ Storage Intervals } & \multirow{2}{*}{ Inc } & \multirow{2}{*}{ Means } \\
\cline { 2 - 10 } & $\begin{array}{c}\text { Initial } \\
\text { Day }\end{array}$ & $\mathbf{1 5}$ & $\mathbf{3 0}$ & $\mathbf{4 5}$ & $\mathbf{6 0}$ & $\mathbf{7 5}$ & $\mathbf{9 0}$ & & \\
\hline $\mathbf{M}_{\mathbf{1}}$ & 15.27 & 15.5 & 16 & 16.5 & 17.1 & 17.8 & 18.3 & 16.56 & $16.63 \mathrm{a}$ \\
\hline $\mathbf{M}_{\mathbf{2}}$ & 14.91 & 15 & 15.3 & 15.5 & 15.9 & 15.1 & 16.35 & 8.81 & $15.43 \mathrm{~b}$ \\
\hline $\mathbf{M}_{\mathbf{3}}$ & 14.39 & 14.5 & 14.8 & 15 & 15.4 & 15.8 & 16.2 & 11.17 & $15.15 \mathrm{bc}$ \\
\hline $\mathbf{M}_{\mathbf{4}}$ & 14.39 & 14.65 & 14.8 & 14.99 & 15.21 & 15.41 & 15.9 & 9.50 & $15.05 \mathrm{c}$ \\
\hline $\mathbf{M}_{\mathbf{5}}$ & 13.42 & 13.62 & 13.83 & 14.13 & 14.34 & 14.56 & 14.9 & 9.93 & $14.11 \mathrm{~d}$ \\
\hline $\mathbf{M}_{\mathbf{6}}$ & 13.4 & 13.6 & 13.79 & 14.1 & 14.27 & 14.39 & 14.5 & 7.59 & $14.00 \mathrm{de}$ \\
\hline $\mathbf{M}_{\mathbf{7}}$ & 13.43 & 13.2 & 13.6 & 13.8 & 13.7 & 13.89 & 14 & 4.07 & $13.66 \mathrm{be}$ \\
\hline Means & $14.17 \mathrm{f}$ & $14.29 \mathrm{ef}$ & $\begin{array}{c}14.58 \mathrm{~d} \\
\mathrm{e}\end{array}$ & $\begin{array}{c}14.86 \mathrm{c} \\
\mathrm{d}\end{array}$ & $\begin{array}{c}15.13 \mathrm{~b} \\
\mathrm{c}\end{array}$ & $\begin{array}{c}15.27 \\
\mathrm{~b}\end{array}$ & $\begin{array}{c}15.73 \\
\mathrm{a}\end{array}$ & & \\
\hline
\end{tabular}

Figures with diverse small letters are statistically diverse $(\mathrm{P}<0.05)$

Table 6. Non-reducing sugar of mango and guava blended squash during storage

\begin{tabular}{|c|c|c|c|c|c|c|c|c|c|}
\hline \multirow[b]{2}{*}{ Treatments } & \multicolumn{7}{|c|}{ Storage Intervals } & \multirow[b]{2}{*}{$\begin{array}{c}\% \\
\text { Dec }\end{array}$} & \multirow[b]{2}{*}{ Means } \\
\hline & $\begin{array}{c}\text { Initial } \\
\text { Day }\end{array}$ & 15 & 30 & 45 & 60 & 75 & 90 & & \\
\hline $\mathbf{M}_{1}$ & 29.22 & 29 & 28.5 & 28 & 27 & 27.1 & 26 & 11.02 & $27.83 b$ \\
\hline $\mathbf{M}_{2}$ & 28.12 & 28 & 27.85 & 27.5 & 27.1 & 26.8 & 26.5 & 5.76 & $27.41 \mathrm{c}$ \\
\hline $\mathbf{M}_{3}$ & 28.3 & 28.2 & 28.05 & 27.85 & 27.6 & 27.45 & 27.37 & 3.29 & $27.83 \mathrm{~b}$ \\
\hline $\mathbf{M}_{4}$ & 28.3 & 28.05 & 27.8 & 27.5 & 27.25 & 27.05 & 26.84 & 5.16 & $27.54 b c$ \\
\hline $\mathbf{M}_{5}$ & 27.2 & 27.1 & 26.8 & 26.4 & 26.1 & 25.8 & 25.5 & 6.25 & $26.41 d$ \\
\hline$M_{6}$ & 28.4 & 28.2 & 28 & 27.85 & 27.5 & 27.37 & 27 & 4.93 & $27.76 \mathrm{~b}$ \\
\hline $\mathbf{M}_{7}$ & 28.6 & 28.5 & 28.4 & 28.28 & 28.14 & 28.05 & 27.5 & 3.84 & $28.26 a$ \\
\hline Means & $28.30 \mathrm{a}$ & $28.15 \mathrm{ab}$ & $27.91 b c$ & $27.62 \mathrm{c}$ & $26.24 d$ & $27.08 \mathrm{~d}$ & $26.67 \mathrm{e}$ & & \\
\hline
\end{tabular}

Figures with diverse small letters are statistically diverse $(\mathrm{P}<0.05)$

Table 7. Color of mango and guava blended squash during storage

\begin{tabular}{|c|c|c|c|c|c|c|c|c|c|}
\hline \multirow{2}{*}{ Treatments } & \multicolumn{7}{|c|}{ Storage Intervals } & \multirow{2}{*}{ Dec } & \multirow{2}{*}{ Means } \\
\cline { 2 - 10 } & Initial Day & 15 & 30 & 45 & 60 & 75 & 90 & & \\
\hline $\mathbf{M}_{\mathbf{1}}$ & 8.9 & 8 & 7.2 & 6.1 & 5.3 & 4.5 & 3.7 & 58.43 & $6.2 \mathrm{~d}$ \\
\hline $\mathbf{M}_{\mathbf{2}}$ & 8.7 & 8.3 & 8 & 7.7 & 7.4 & 7 & 6.8 & 21.84 & $7.7 \mathrm{a}$ \\
\hline $\mathbf{M}_{\mathbf{3}}$ & 8.6 & 8.4 & 8.1 & 7.9 & 7.7 & 7.3 & 7 & 18.60 & $7.9 \mathrm{a}$ \\
\hline $\mathbf{M}_{\mathbf{4}}$ & 8.4 & 8.1 & 7.8 & 7.5 & 7.2 & 6.9 & 6.6 & 21.43 & $7.5 \mathrm{ab}$ \\
\hline $\mathbf{M}_{\mathbf{5}}$ & 7.4 & 7.2 & 6.9 & 6.7 & 6.4 & 6 & 5.7 & 22.97 & $6.6 \mathrm{~cd}$ \\
\hline $\mathbf{M}_{\mathbf{6}}$ & 7.7 & 7.5 & 7.3 & 7 & 6.7 & 6.4 & 6.2 & 19.48 & $6.97 \mathrm{bc}$ \\
\hline $\mathbf{M}_{\mathbf{7}}$ & 8 & 7.8 & 7.6 & 7.4 & 7.1 & 6.9 & 6.5 & 18.75 & $7.4 \mathrm{a}$ \\
\hline $\mathbf{M e a n s}$ & $8.2 \mathrm{a}$ & $7.9 \mathrm{ab}$ & $7.5 \mathrm{bc}$ & $7.1 \mathrm{~cd}$ & $6.8 \mathrm{de}$ & $6.42 \mathrm{ef}$ & $6.07 \mathrm{f}$ & & \\
\hline
\end{tabular}

Figures with diverse small letters are statistically diverse $(\mathrm{P}<0.05)$ 
Table 8. Flavor of mango and guava blended squash during storage

\begin{tabular}{|c|c|c|c|c|c|c|c|c|c|}
\hline \multirow{2}{*}{ Treatments } & \multicolumn{7}{|c|}{ Storage Intervals } & \multirow{2}{*}{ Dec } & \multirow{2}{*}{ Means } \\
\cline { 2 - 10 } & $\begin{array}{c}\text { Initial } \\
\text { Day }\end{array}$ & $\mathbf{1 5}$ & $\mathbf{3 0}$ & $\mathbf{4 5}$ & $\mathbf{6 0}$ & $\mathbf{7 5}$ & $\mathbf{9 0}$ & & \\
\hline $\mathbf{M}_{\mathbf{1}}$ & 9 & 8 & 7.3 & 6 & 5 & 4.2 & 3.5 & 61.11 & $6.1 \mathrm{c}$ \\
\hline $\mathbf{M}_{\mathbf{2}}$ & 8.8 & 8.4 & 8.1 & 7.7 & 7.3 & 6.8 & 6.4 & 27.27 & $7.6 \mathrm{ab}$ \\
\hline $\mathbf{M}_{\mathbf{3}}$ & 8.7 & 8.5 & 8.2 & 8 & 7.7 & 7.4 & 7.2 & 17.24 & $8.0 \mathrm{a}$ \\
\hline $\mathbf{M}_{\mathbf{4}}$ & 8.3 & 8 & 7.6 & 7.1 & 6.7 & 6.4 & 6 & 27.71 & $7.2 \mathrm{~b}$ \\
\hline $\mathbf{M}_{\mathbf{5}}$ & 8.2 & 8 & 7.7 & 7.4 & 7.1 & 6.7 & 6.3 & 23.17 & $7.3 \mathrm{a}$ \\
\hline $\mathbf{M}_{\mathbf{6}}$ & 8.3 & 8.1 & 7.8 & 7.6 & 7.3 & 6.9 & 6.6 & 20.48 & $7.5 \mathrm{a}$ \\
\hline $\mathbf{M}_{\mathbf{7}}$ & 8.4 & 8.2 & 8 & 7.8 & 7.5 & 7.3 & 6.9 & 17.85 & $7.7 \mathrm{ab}$ \\
\hline $\mathbf{M e a n s}$ & $8.5 \mathrm{a}$ & $8.1 \mathrm{ab}$ & $7.8 \mathrm{bc}$ & $7.3 \mathrm{bc}$ & $6.9 \mathrm{de}$ & $6.5 \mathrm{ef}$ & $6.12 \mathrm{f}$ & & \\
\hline
\end{tabular}

Figures with diverse small letters are statistically diverse $(\mathrm{P}<0.05)$

Table 9. Overall acceptability of mango and guava blended squash during storage

\begin{tabular}{|c|c|c|c|c|c|c|c|c|c|}
\hline \multirow[b]{2}{*}{$\begin{array}{c}\text { Treatment } \\
\mathrm{S}\end{array}$} & \multicolumn{7}{|c|}{ Storage Intervals } & \multirow[b]{2}{*}{$\%$ Dec } & \multirow[b]{2}{*}{ Means } \\
\hline & $\begin{array}{c}\text { Initial } \\
\text { Day }\end{array}$ & 15 & 30 & 45 & 60 & 75 & 90 & & \\
\hline $\mathbf{M}_{1}$ & 8 & 7.3 & 6.6 & 6 & 5.2 & 4.5 & 3.8 & 52.50 & $5.9 \mathrm{~b}$ \\
\hline $\mathbf{M}_{2}$ & 8 & 7.8 & 7.6 & 7.3 & 6.9 & 6.6 & 6.3 & 21.25 & $7.2 \mathrm{a}$ \\
\hline $\mathbf{M}_{3}$ & 8 & 7.8 & 7.6 & 7.4 & 7.2 & 7 & 6.8 & 15.00 & $7.4 \mathrm{a}$ \\
\hline $\mathbf{M}_{4}$ & 8 & 7.7 & 7.4 & 7.1 & 6.9 & 6.6 & 6.4 & 20.00 & $7.1 \mathrm{a}$ \\
\hline$M_{5}$ & 8 & 7.7 & 7.5 & 7.2 & 6.8 & 6.5 & 6.2 & 22.50 & $7.1 \mathrm{a}$ \\
\hline$M_{6}$ & 8 & 7.7 & 7.6 & 7.4 & 7.1 & 6.8 & 6.6 & 17.50 & $7.3 \mathrm{a}$ \\
\hline $\mathbf{M}_{7}$ & 8 & 7.9 & 7.8 & 7.6 & 7.4 & 7.2 & 6.8 & 15.00 & $7.5 \mathrm{a}$ \\
\hline Means & $8.0 \mathrm{a}$ & $7.7 \mathrm{ab}$ & $7.4 \mathrm{bc}$ & $7.1 \mathrm{~cd}$ & $6.7 \mathrm{de}$ & $6.4 \mathrm{ef}$ & $6.1 \mathrm{f}$ & & \\
\hline
\end{tabular}

Figures with diverse small letters are statistically diverse $(\mathrm{P}<0.05)$

\section{Conclusion and recommendations}

It is concluded from this research work that sample $\mathrm{M}_{3}$ (700ml mango and $300 \mathrm{ml}$ guava) which was treated with $0.1 \%$ potassium meta bisulphite as chemical preservative was found best on the basis of physicochemical analysis such as $\mathrm{pH}$ (2.84d), \%acidity (1.39ab), Total soluble solids (47.9c ${ }^{0}$ Brix), Reducing sugar (15.15bc\%), Non reducing sugar (27.83b\%), Ascorbic acid(34.09b $\mathrm{mg} / 100 \mathrm{~g}$ ) and sensory evaluation such as color (7.9a), flavor (8.0a) and overall acceptability (7.4a) as compared to other treatments. From this study it is concluded that mango and guava blended squash $\mathrm{M}_{3}$ (700ml mango and $300 \mathrm{ml}$ guava) were accepted both organoleptically and physicochemically as compared to others.

\section{Authors' contributions}

Conceived and designed the experiments: MN Din \& S Wahab, Performed the experiments: MN Din, Analyzed the data:
MN Din \& S Wahab, Contributed reagents/ materials/ analysis tools: S Wahab, A Muhammad, H Bilal, MU Din, H Nawaz, SA Khan \& QA Sultan, Wrote the paper: MN Din.

\section{References}

1. Nakasone HY \& Paull RE (1998). Tropical fruits. Wallirgford. CAB Queensland Agri $J$ III (2): 93-98.

2. Menzel CM (1995). Guava: An exotic fruit with potential in Queensland. $C A B$ Queensland Agri J I (2): 87- 92.

3. Mortin JF (1987). Longan. In: Julia F Morton (Ed.), Fruits of warm climates, Miami, FL, pp 259-262.

4. Singh BP, Kalra SK, \& Tandon DK (1990). Behaviour of guava cultivars during ripening and storage. Haryana $J$ of Horticul Sci 19(1-2): 1-6.

5. Anka LM (2003). Marketing of agricultural products in Pakistan. J Rural Dev and Admin 27(1): 95-102

6. Agricultural Statistic of Pakistan (20045).Govt. of Pakistan, Ministry of Food, 
Agric and Livestock Economic Wing Islamabad.

7. Ashoush IS \& Gadallah MGE (2011). Utilization of mango peels and seed kernels powders as sources of phytochemicals in biscuits. World $J$ of Dairy and Food Sci 6 (1): 35-42.

8. Anonymous (2010). Economic Survey of Pakistan. Economic Advisor's Wing, Finance Division, Govt. of Pakistan, Islamabad.

9. Malik MA, Haq MA \& Muhammad N (1994). Prospectus of mango processing in Pakistan, In; A Saeed (Ed.), Mango, A Brochure of the Horticulture Foundation of Pakistan, Islamabad.

10. Gupta RK (1993). Handbook of Export Oriented Food Processing Projects. SBP Consultants and Engineers. Pvt Ltd. 314315.

11. Awan JA \& Salim UR (1997). Food analysis manual, Vet Ag publication 5: 27.

12. AOAC (2012). Official methods of analysis association of official \& analytical chemist's $13^{\text {th }}$ edi. Washington, DC.

13. Larmond E (1977). Laboratory method of sensory evaluation of food. Publication of Deptt: Agri Ottawa, Canada. Pp 177-183.

14. Gomez KA, \& AA Gomez (1984). Statistical Procedure for Agricultural Research. $2^{\text {nd }}$ edition, pp 8-22.

15. Steel RG \& Torrie JH (1997). Principles and procedures of statistics. A biometrical approach, $2^{\text {nd }}$ ed. New York, McGrawHill, pp 633.

16. Nath A, Yadav DS, Sarma P \& Dey B (2005). Standardization of ginger-kinnow squash and its storage. J Food Sci Tech 42: 520-522.

17. Archana P (2005). Studies on preparation and storage of tamarind squash. $J$ of Spp and Aromatic Crops 24(1): 37-42.

18. Gajanana K (2002) Processing of aonla (Emblica officinalis Gaertn.) fruits. M.Sc. (Hort.) Thesis, University of Agriculture Sciences, Dharwad, India.

19. Lakshmi K, Kumar AKV, Rao LJ \& Naidu MM (2005). Quality evaluation of flavoured RTS beverage and beverage concentrate. J Food Sci Tech 42: 411-414.
20. Nidhi, Gehlot R, Singh R \& Rana MK (2008). Changes in chemical components of RTS bael- guava blended beverages during storage. J Food Sci Tech 45: 378380

21. Kotecha PM \& Kadam SS (2003). Preparation of ready-to-serve beverage, syrup and concentrate from tamarind. $J$ of Food Sci Tech 40(1): 76-9.

22. Lee SK \& Kader AA (2000). Preharvest and postharvest factors influencing vitamin $\mathrm{C}$ content of horticultural crops. $J$ Postharvest Biol and Technol 1: 20(3):207-20.

23. Basavaraja PS (2005). Value added products from rose apple (Syzigium jambos Alston). M.Sc. (Hort.) Thesis, University of Agriculture Sciences, Bengaluru.

24. Sahu C, Choudhary PL, Patel S \& Sahu R (2006) Physico-chemical and sensory characteristics of whey based mango herbal (lemongrass) beverage. Ind $F d$ Packer 60: 127-132.

25. Ruiz Nieto A, Lopez AJM, Lopez MR, Lopez MJ, Medina JJ, Scheer HAT, Lieten F \& Dijkstra J (1997). Analysis of sugars from strawberry cultivars of commercial interest-content evolution. Proceedings of the third international strawberry symposium. Veldhoven, Netherlands. 29(2). Acta Horticulturae 493: 663-667.

26. Jennifer AS (1993). Colour influences flavour indentificaion in fruit flavoured beverages. J Food Sci 58(4): 810-812.

27. Rani S (2010). Quality evaluation of kinnow and strawberry blended juice. M.Sc. Thesis. Dept of Food Sci \& Tech Agri Uni Peshawar.

28. Martin JJ, Solances, Solances E, Bota E \& Sancho J (1995). Chemical and organoleptic changes in pasteurized orange juice. Alimentaria 216: 59-63.

29. Paracha, GM (2009). Development and storage stability of low caloric guava squash. M.Sc. Thesis. Dept of Food Sci \& Tech Agri Uni Peshawar.

30. Rozario, MJG (1996). Formulation of ready to drink blends from fruits and vegetables juices. $J$ of Philippines 9(3): 201-209. 